\title{
Palliative care: epidemiological profile with a biopsychosocial look on oncological patients
}

\author{
Cuidados paliativos: perfil com olhar biopsicossocial dentre pacientes oncológicos
}

Karoline Sampaio Castôr ${ }^{1}$, Ed Carlos Rey Moura², Emanuel Cabral Pereira ${ }^{3}$, Deborah Costa Alves ${ }^{3}$, Thamires Sales Ribeiro ${ }^{3}$, Plínio da Cunha Leal ${ }^{2}$

\section{ABSTRACT}

BACKGROUND AND OBJECTIVES: Palliative care is a set of practices that encompasses patients with life-threatening diseases which approach is no longer curative, but comforting, including care for the family. The objective of this study was to verify the epidemiological profile of cancer patients in palliative care.

METHODS: We interviewed 100 cancer patients in palliative care, as well as the sociodemographic and biopsychosocial variables, using the Karnofsky index, Palliative Performance Scale and Edmonton Symptom Assessment Scale.

RESULTS: The prevalent age group was between 51-60 years (34\%), more than half female $(77 \%)$, incomplete elementary school (40\%) and resident in the interior of Maranhão (73\%). Concerning the use of pain drugs, $52 \%$ reported not forgetting to take their pain drug, while $56 \%$ took drug on their own. As to the diagnosis, only $13 \%$ of the interviewees were aware of a palliative diagnosis, and more than half of them were aware of primary or oncological diagnosis (65\%). Regarding the evaluation of functional capacity, $52 \%$ had the Karnofskys index between 70 and 90\%; Palliative Performance Scale, 62\% between 80 and 90\%, and Edmonton Symptom Assessment Scale the following most significant variables in tiredness, (60\%); sadness, (84\%); anxiety, (73\%); lack of appetite, (51\%) and absence of well-being (79\%).

\footnotetext{
Karoline Sampaio Castôr - (Dhttps://orcid.org/0000-0001-7635-8752;

Ed Carlos Rey Moura - Dhttps://orcid.org/0000-0002-7752-0683;

Emanuel Cabral Pereira - (Dhttps://orcid.org/0000-0003-4227-1944;

Deborah Costa Alves - (Dhttps://orcid.org/0000-0001-9063-854X;

Thamires Sales Ribeiro - (Dhttps://orcid.org/0000-0002-7063-7539;

Plínio da Cunha Leal - (Dhttps://orcid.org/0000-0003-1336-8528.

1. Universidade Ceuma, Faculdade de Medicina, Departamento de Ciências da Saúde, Săo Luís, MA, Brasil.

2. Universidade Federal do Maranhẫo, Hospital São Domingos, Departamentos de Medicina I e Anestesiologia, São Luís, MA, Brasil.

3. Universidade Federal do Maranhão, Faculdade de Medicina, Centro de Ciências Biológicas e da Saúde, São Luís, MA, Brasil.
}

Submitted in July 19, 2018.

Accepted for publication in December 10, 2018.

Conflict of interests: none - Sponsoring sources: none

Correspondence to:

R. Seroa da Mota, 23 - Apeadouro

65031-630 São Luís, MA, Brasil.

E-mail: karoline.sampaio@hotmail.com

(C) Sociedade Brasileira para o Estudo da Dor
CONCLUSION: Knowing the profile of patients is key to identify the obstacles to the effective implementation of palliative care, making it possible to implement targeted measures.

Keywords: Epidemiological profile, Oncology, Palliative care.

\section{RESUMO}

JUSTIFICATIVA E OBJETIVOS: Os cuidados paliativos são um conjunto de práticas que abrangem pacientes portadores de doenças ameaçadoras da vida e cuja abordagem deixa de ser curativa e passa a ser baseada em conforto, incluindo cuidados com a família. O objetivo deste estudo foi verificar o perfil epidemiológico de pacientes oncológicos em cuidados paliativos.

MÉTODOS: Foram entrevistados 100 pacientes oncológicos em cuidados paliativos quanto às variáveis sociodemográficas e biopsicossociais, utilizando-se o índice de Karnofsky, a Escala de Performance Paliativa e a Escala de Avaliação de Sintomas de Edmonton. RESULTADOS: Observou-se faixa etária mais prevalente entre 51 e 60 anos (34\%), mais da metade do sexo feminino (77\%), nível escolar fundamental incompleto $(40 \%)$ e residente no interior do Maranhão (73\%). Quanto ao uso de analgésicos, 52\% relataram não esquecer de tomar o fármaco para dor; enquanto $56 \%$ tomam fármaco por conta própria. Quanto ao diagnóstico, apenas $13 \%$ dos entrevistados conhecem o diagnóstico paliativo, e mais da metade conhece o diagnóstico primário ou oncológico (65\%). Quanto à avaliação da capacidade funcional, 52\% tem índice de Karnofsky avaliado entre 70 e 90\%; Escala de Performance Paliativa, 62\% estão entre 80 e 90\% e Escala de Avaliação de Sintomas de Edmonton as seguintes variáveis mais significantes em cansaço, (60\%); tristeza, (84\%); ansiedade, (73\%); falta de apetite, (51\%) e ausência de bem-estar (79\%).

CONCLUSÁO: Conhecer o perfil de pacientes é relevante para a identificação pontual de obstáculos na implementação efetiva dos cuidados paliativos. Possibilitando assim, a implementação de medidas direcionadas.

Descritores: Cuidados paliativos, Oncologia, Perfil epidemiológico.

\section{INTRODUCTION}

According to the Brazilian National Academy of Palliative Care (ANCP), in its manual of $2012^{1}$, palliative care has historically been associated with the term Hospice. This word comes from the start of the Christian age when these institutions played a role in the spread of Christianity through Europe. The original Hospices were shelters (like hostels) which would welcome and take care of pilgrims and travelers, 
and the first report on these dated from the $5^{\text {th }}$ Century when Fabiola, a disciple of St Jerome, would care for travelers coming from Asia, Africa, and other Eastern countries, at the Hospice of the Port of Rome. Etymologically, the word 'palliative' comes from the verb palliare, which means cloak or mantle (protection); hence the verb 'paliar' has acquired many meanings, such as: to make something less hard, to remedy, to soothe or relieve. The concept of palliative care (PC) is based on this notion, as palliative treatment is a kind of treatment that "gives a momentary remedy for the solution of a problem yet does not solve the problem permanently"

According to the definition of the World Health Organization (WHO), reviewed in $2002^{3}$, Palliative Care is an approach which implements and promotes quality of life (QoL) of patients and their families, when the patients have illnesses that threaten the continuity of their lives, through prevention and relief of suffering. This approach requires early identification, evaluation, and treatment of pain and any other problems of physical, psychosocial and spiritual nature". PC is based on principles, rather than protocols. Nowadays, no one talks about terminality, but rather of illness that threatens life. Care right from the moment of diagnosis is also recommended, expanding this field of action. Similarly, no mention shall be made of the impossibility of cure; instead, one shall mention the possibility of treatment to modify the illness, thereby removing the concept that "nothing else can be done". For the first time ever, an approach includes spirituality as one of the dimensions of the human being. The family is also remembered, and therefore provided with assistance, even after the death of the patient, during the period of mourning ${ }^{1}$.

Ideologues and palliativist professionals believe that those who work exclusively towards a cure end up not realizing the true limits of their practical activities, as also the limits applicable when dealing with the patient, his or her feelings, and his or her reactions. The main criticisms show that this excess of medical power produces what has been defined as "therapeutic imprisonment," perceived by those who believe in the idea of PC as an invasion of the sick body. The proposal of $\mathrm{PC}$ is therefore regarded as a move to break this paradigm and thus construct a new style of medicine, with the exercise of medical power being expanded and made more sophisticated, in a mediating way and together with the interdisciplinary team. The palliativists also work with the acceptance of the inevitable worsening of the disease and try to minimize pain, so that the patient may live through this process with QoL ${ }^{4}$.

The new Brazilian Code of Medical Ethics 5 , approved by Resolution 1.931/09 of the Federal Medical Council (CFM), has helped towards greater dissemination of the philosophy of Palliative Care and advises the doctor to avoid therapeutic obstinacy for terminally ill patients.

"Good death" should respect the 12 aspects identified by a British group studying the health of the elderly. For a "good death", the patients need to know that death is nigh and understand what can be expected, be able to maintain control over what is happening; be given due privacy and dignity; have control over pain relief and other symptoms; be able to choose where death occurs (whether at home or in some other location); have access to any kind of information or knowledge; have access to spiritual and emotional support; have access to PC anywhere, and not just in hospital; have control over who is present, and who the end shall be shared with; be able to issue advance guidance so that the patient's wishes may be respected; have time to say goodbye and have control over other time issues; and be able to leave at the right time, not having life prolonged uselessly $y^{6,7}$.

The purpose of this study was to check the epidemiological profile of cancer patients in PC, attended to by a cancer hospital in the Brazilian state of Maranhão. By constructing the profiles of the patients, it is possible to develop new implementation strategies and patient care.

\section{METHODS}

This is a longitudinal, prospective, observational and quantitative study. One hundred patients under PC were interviewed at the 'Aldenora Bello' cancer hospital in the city of São Luís, capital of the state of Maranhão, Brazil. The sample was found by free demand in the outpatient pain unit of this hospital, or during hospitalization, and was chosen at random up to $n=100$. The calculation of the sample within a population of 156 people, with a confidence rate of $90 \%$, with an error margin of $5 \%$. The formula for the calculation of the size of the sample for a reliable estimate of the mean for the population $(\mu)$ is given by:

$$
\mathrm{n}=\left(\frac{Z_{\alpha / 2} \cdot \sigma}{E}\right)^{2}
$$

In this formula, $\mathrm{n}$ is the number of individuals in the sample, $\mathrm{Z}_{\alpha / 2}$ is the critical value which corresponds to the degree of confidence as requested, and $\sigma$ is the standard deviation (SD) of the variable studied. $\mathrm{E}$ is the margin of error or the maximum error for estimation. This identifies the maximum difference between the sample mean $(\mathrm{X})$ and the true mean of the whole population.

The criteria for exclusion were patients undergoing curative treatment; patients from the private hospital network; patients who were cognitively unable to answer the questions; patients who did not agree to participate in the research or who decided not to participate in the research later on. The main criteria of inclusion were cancer patients in PC in the public health sector of the hospital here identified, from March 2017 until the required number of patients (n) for the sample was obtained. There were no cases of people who decided not to participate or refused to be interviewed. All the patients who took part in this study signed the Free and Informed Consent Form (FICT).

The material used for data collection was a closed questionnaire with socio-demographic questions including age, gender, ethnicity, educational level, and origin; and also, objective questions about awareness of the patient's diagnosis and prognosis, and validated scales of functional and psycho-affective evaluation. The instruments or scales used in the said questionnaire were the Karnofsky score, the Palliative Performance Score (PPS) and the Edmonton Symptom Assessment (ESAS), all these having been validated.

The Karnofsky score describes the growing levels of activity and independence, with values ranging from zero to 100 , where zero corresponds to death, and 100 represents a normal level of physical performance and aptitude to carry out normal activities, especially those involving self-care. In adaptation, the lowest index is 10 , meaning that the patient is about to die, and in a process where death is rapidly progressing. This is the instrument most commonly used in the prognosis of cancer therapy, as this is a measure of performance for the classification of a person's skills to carry out activities, by evaluating the progress 
of the patient after therapeutic procedures or establishing the patient's capacity of receiving therapy ${ }^{8}$.

PPS is an instrument that has been validated and is widely used within PC to follow and monitor the evolutive curve of the illness, thereby establishing grounds for decision-making, expectations of prognosis, and definition of terminality. Among other factors, the PPS evaluates the severity of the disease, and the patient's capacity to take care of himself. An accurate estimate of the prognosis helps to plan the medical action, and also establishes the best moment to prioritize PC rather than curative measures, also identifying when this first type of treatment becomes exclusive? ${ }^{9}$ ESAS is a scale for evaluation and monitoring of physical and psychological symptoms that use of the following variables: pain, fatigue, nausea, depression, anxiety, drowsiness, appetite, well-being, shortage of breath, and some blank space so that the patient may add any other symptoms experienced. ESAS was developed by Bruera et al. ${ }^{10}$, at the Unit for Cancer Patients in Palliative Care at the General Hospital at Edmonton, Canada. It comprises 10 items, each being linked to a visual numeric scale (VNS) ranging from zero to 10 , where zero represents the absence of the symptom and 10 means that the symptom shows its most extreme manifestation. The authors later added one of the items (shortage of breath), and there was also a shift from the visual analog scale (VAS) to VNS, as it is currently known.

ESAS is a scale that is valid for control and handling of symptoms, as it is easy, simple, and quick to use ${ }^{11}$.

This whole research project was based on Resolution No. 466/12 of the National Health Council (CNS), which establishes guidelines and standards to regulate research involving human subjects. The Research Ethics Committee approved the study under opinion No.1,939,689, of 2017.

\section{Statistical analysis}

All the data collected were tabulated and then statistically analyzed using Microsoft Excel 2013. The results were shown in the descriptive and tabular form. Initially, the analysis using descriptive statistics was made through frequency tables for the variables as analyzed, we estimated the mean, standard deviation, and maximum and minimum of the numerical variables. The level of significance to reject the hypothesis of nullity was $5 \%$, which means that any p-value less than 0.05 $(\mathrm{p}<0.05)$ was considered statistically significant.

\section{RESULTS}

The evaluation was carried out on 100 patients under PC at a specialized cancer hospital in the capital of the state of Maranhão, through the application of a quantitative questionnaire, considering social and demographic data. We observed that in the population prevailed the age group from 51 to 60 years (34\%), females (77\%), brown (51\%), black (28\%) and white (21\%). Regarding marital status, 67\% reported having a fixed partner. Sixty-two percent of the sample population were Evangelical Christians. Forty percent did not finish their primary education; 73\% lived in the interior of the state of Maranhão, and $92 \%$ did not work. Out of the patients in the sample, 54\% were unaware of the legal rights of patients with cancer; $94 \%$ had a caregiver, whether a family member or not; $82 \%$ did not know how to use the Internet to learn more about their diagnosis.
Regarding the use of medication for pain relief, we observed that $52 \%$ of the subjects mentioned that they never forget to take their medicines for pain relief; $57 \%$ mentioned that they do not stop taking medicine for pain relief when they feel better; $56 \%$ reported self-medication, and $78 \%$ said they never set their alarm clocks to remind them about medication times (Table 1). We also observed that $13 \%$ of the people interviewed knew about palliative diagnosis, while $87 \%$ did not (Table 2).

Concerning primary diagnosis, we noticed that $65 \%$ are aware of the diagnosis of cancer, while 35\% are not. Regarding the advanced healthcare directive, $100 \%$ of the sample was unaware. Another fact observed is the fact that $92 \%$ of subjects did not have any physical exercise activity.

Table 1. Distribution of patients under palliative care evaluated according to their regular use of drugs. São Luís, 2018

\begin{tabular}{lcc}
\hline Variables & \multicolumn{2}{c}{ Sample } \\
& \multicolumn{2}{c}{$\mathrm{n}=100$} \\
& Yes & No \\
\hline Forget to take medication for pain relief & 48 & 52 \\
Stop taking medication when feeling better & 43 & 57 \\
Take medicines through self-medication & 56 & 44 \\
Set the alarm clock to ring at medicine times & 22 & 78 \\
\hline
\end{tabular}

Table 2. Distribution of patients under palliative care evaluated according to the knowledge of palliative diagnosis and primary diagnosis. São Luís, 2018

\begin{tabular}{lcc}
\hline Variables & \multicolumn{2}{c}{ Sample } \\
& \multicolumn{2}{c}{$n=100$} \\
& Yes & No \\
\hline Aware of primary or oncological diagnosis & 65 & 35 \\
Aware of palliative diagnosis & 13 & 87 \\
\hline
\end{tabular}

Considering the evaluation of functional capacity, we saw that $52 \%$ of the patients had a Karnofsky score between $70 \%$ and $90 \%$; a total of $9 \%$ of these correspond to a Karnofsky score of 70\%: there is no need for assistance for personal care, but the person is unable to carry out normal activities such as household chores and active tasks. A further $12 \%$ had a Karnofsky score of $80 \%$, which means that these people can carry out normal tasks, albeit with effort. These people also showed some signs and symptoms of the illness, but incapacity is only present for activities requiring a lot of effort. Finally, 31\% of the sample shows a Karnofsky score of $90 \%$, meaning a capacity to carry out normal tasks; signs and symptoms of the disease are minimal among these people (Table 3).

Table 3. Distribution of patients under palliative care evaluated based on their functional capacity, according to the Karnofsky scale. São Luís, 2018

\begin{tabular}{lc}
\hline Variables & Sample $(\mathrm{n}=100)$ \\
\hline Functional capacity of $80 \%$ & $12 \%$ \\
Functional capacity of $90 \%$ & $31 \%$ \\
Functional capacity of $70-90 \%$ & $52 \%$ \\
\hline
\end{tabular}

Turning now to PPS, we saw that $62 \%$ of the subjects had PPS scores between 80 and $90 \%$; of these, $34 \%$ have a PPS of $80 \%$ : total ambulation, activities with effort, some evidence of the disease, carries out full 
self-care, normal ingestion, and level of consciousness preserved. Twenty-eight percent have a PPS of $90 \%$, which entails full ambulation, normal activities, some evidence of the disease, execution of full self-care, normal ingestion, and level of consciousness preserved (see Table 4).

Table 4. Distribution of patients under palliative care evaluated by functional capacity according to PPS. São Luís, 2018.

\begin{tabular}{lc}
\hline Variables & Sample $(\mathrm{n}=100)$ \\
\hline PPS $80 \%$ & $34 \%$ \\
PPS 90\% & $28 \%$ \\
PPS $80-90 \%$ & $62 \%$ \\
\hline
\end{tabular}

Moving on to ESAS, we saw that the following variables showed: pain ( $53 \%$ between 2 and 5); fatigue ( $60 \%$ between 6 and 9); nausea ( $58 \%$ between 1 and 4); sadness (84\% between 6 and 9); anxiety (73\% between 6 and 9); drowsiness (55\% between 4 and 7); lack of appetite ( $51 \%$ between 6 and 9); lack of well-being (79\% between 6 and 9), and shortage of breath (61\% between 1 and 4$)$. Others not reported (Table 5).

Table 5. Distribution of patients under palliative care, evaluated by their functional capacity, using ESAS. São Luís, 2018

\begin{tabular}{lc}
\hline Variables ESAS & Sample $\mathrm{n}=100$ \\
\hline Point score from zero to 10 & \\
Pain, score between 2 and 5 & $53 \%$ \\
Fatigue, between 6 and 9 & $60 \%$ \\
Nausea, between 1 and 4 & $58 \%$ \\
Sadness, between 6 and 9 & $84 \%$ \\
Anxiety, between 6 and 9 & $73 \%$ \\
Drowsiness, between 4 and 7 & $55 \%$ \\
Loss of appetite, between 6 and 9 & $51 \%$ \\
Lack of well-being, between 6 and 9 & $79 \%$ \\
Shortage of breath, between 1 and 4 & $61 \%$ \\
Others & $0 \%$ \\
\hline
\end{tabular}

\section{DISCUSSION}

The demographic transition in Brazil started with the decline in mortality rates and then, after some time, with a decrease in birth rates, thereby bringing about significant changes in the age structure of the Brazilian population ${ }^{12}$. According to Carneiro et al. ${ }^{13}$, with the recent aging process among the population, which predicts an exponential growth in the number of elderly people, it is also possible to predict that there shall be a sharp increase in the prevalence of cancer and other chronic degenerative diseases such as hypertension, diabetes mellitus, and diseases of the bones and joints. The values corresponding to the age, gender and educational level in this study correspond to what was expected when we compared with the findings of specialized literature.

The higher occurrence among females is also the expected profile for emerging countries ${ }^{14}$, where the number of cases of cancer among women is higher than among men ${ }^{14}$. Here it is also worth pointing out that the female population is also the segment of the population that goes to the doctor earlier and more often, which could be one reason why cancer appears to be more common among women. In this perspective, in most cases, men tend to suffer more from severe and chronic health conditions than women do and also die earlier than they $\mathrm{do}^{15}$.

Over half the population studied reported a fixed partner and a specific caregiver. The literature shows that support from the spouse or other family members is, indeed, very important for people with a life-threatening disease. It is also evident that a person with cancer tends to adapt better to situations of life-threatening diseases and the stress that this condition brings when there is a high level of social and family support ${ }^{16}$.

On the other hand, the burden overload on the caregiver is often linked to episodes of depression, anxiety, physical and mental fatigue, stress, and worse QoL for the patient, which could even generate risks for the patient's physical and psychological health ${ }^{17}$. The family members and caregivers, whether these are part of the family or not, should be part of the medical and multiprofessional assistance involved in palliative care ${ }^{1}$. The human being is not isolated but leads a life that is inserted in a biological, psychological and social context. Therefore, looking in one direction is not just a flaw in care for the patient-family axis, but is also a flaw in the formation of the medical and professional concepts behind health issues, which propose the defense of life.

The State of Maranhão has publicly owned Oncology Centers in the regions around the cities of Caxias and Imperatriz, in a move to reduce the flow of patients at Cancer Hospitals in the state capital. However, most of the people surveyed (73\%) live in the countryside of the State of Maranhão, which could lead to an overload of the health system under study, and maybe the most seriously ill patients may not even be able to get to the hospital. Another relevant fact is that nearly all the patients interviewed do not have paid work, and most of them do not even know the rights of the cancer patient, such as retirement on the grounds of invalidity, and a financial bonus for illness (sick pay). The continuous travel involved generates costs, inconvenience, and emotional problems involving the treatment of the patient, including the family, leading to absences at outpatient appointments or cases where only a representative appears. According to Carvalho and Parsons $^{1}$, the goals of CP include the provision of comfort to the patient; reduction of emotional stress; better QoL, and lower quantity (or complete absence) of invasive intervention. This means that the physical distance between the care team and the patient is also a relevant factor for the implementation of a PC in an efficient manner.

Most of the population under study has not completed primary education. According to some studies related to the diagnosis of cancer, a low educational level, linked to low income, is a factor that affects access to health services, thereby leading to a delay in seeking health care, and to a reduction in the number of preventive examinations such as mammograms and pap smears and prostate tests ${ }^{18-20}$.

The low educational level is also linked to the late diagnosis of cancer and, hence, to higher mortality, not to mention the association to worse standards of health care ${ }^{21}$. Indeed, the higher the educational level, the greater shall be the patient's understanding of QoL, basic sanitation, and health criteria. Therefore, people with more elaborate concepts of health shall have a better perception of painful situations, while people with less knowledge about what an ideal state of health is shall have greater "tolerance" to pain. They can be less demanding in this appraisal of their own state of health, thereby delaying the act of seeking a health service and possibly also delaying the diagnosis. 
This fact is a major cause for concern, as the patient and/or the caregiver should understand as much as possible, to correctly implement the guidance related to health and specific treatment. This data can be even more alarming if we consider the quality of education, a factor that can underestimate the true social and cultural level of this population. The understanding is directly related to greater participation in treatment and to the involvement of the person as an active participant in decision-making with regard to self and proposed interventions. According to Carvalho e Parsons ${ }^{1}$, autonomy is one of the pillars of PC, making the subject become more participant in making decisions, thereby establishing a better relationship between doctor and patient ${ }^{22,23}$.

In this study, we saw a very fine line drawn between those patients who made adequate use of drugs for pain and those who did not. It was also observed that a substantial part of the sample said that they do not forget to take the drugs for pain relief, and neither do they stop taking the medication when they feel better. More than half said that they make use of self-medication, and similarly, the overwhelming majority do not have the habit of setting their alarm clock to go off at medication times, mentioning that they take their medication at times close to those recommended by the doctor.

The main disadvantage in not treating oncological pain, or in treating this pain incorrectly, is that the prognosis is then poor, and there could be a rise in complications arising from the disease, which in turn raises the occurrence of deterioration of the general clinical health of the patient. Treatment of pain brings a significant relief of the associated symptoms ${ }^{24,25}$. It is well known that untreated pain leads to anxiety and depression, thereby worsening such losses and harming cognitive functions, daily activities, social activities and sleep pattern ${ }^{26}$.

We also see that over half the population studied in this research had a Karnofsky score between 70 and $90 \%$ and PPS between 80 and $90 \%$. Percentages corresponding to the ability for self-care, the performance of daily activities in an autonomous way and with the level of consciousness preserved, gives the idea that PC is not a synonym of terminality of the disease, imminent death, or end of life. Another datum within this context that called our attention is the fact that nearly all the interviewees did not practice physical exercises, even though they are statistically capable of doing so. Physical activity is proven to be associated with modulation of pain, improvement of stress and general mood, and is also linked to the reduction of depression. A review carried out by Courneya et al. ${ }^{27}$ in more than 40 studies investigating the practice of physical activities and QoL in cancer patients showed that physical activity, during chemotherapy and radiotherapy during post-treatment, showed good benefits in QoL, with the improvement of general physical skills, body composition, and reduction of fatigue. Physical exercise, indeed, seems to influence the defense of the host against cancer. Pedroso, Araújo and Stevanato ${ }^{28}$ mentioned that physical exercise during the period of treatment could help to activate biological mechanisms, increasing the presence of enzymes that act upon free radicals and Natural Killer cells, meaning that tumors are less likely to form.

On the ESAS scale, we found variables with intensity levels greater than 5 , on a scale ranging from zero to 10 . The following variables were observed over the median: fatigue ( $60 \%$ with scores of 6 to 9 ); sadness ( $84 \%$ between 6 and 9); anxiety (73\% between 6 and 9); loss of appetite (51\% between 6 and 9) and lack of well-being (79\% between 6 and 9). These values agree with the findings of the literature that the prevalence of anxiety and depression among patients living with cancer is higher than that in the general population ${ }^{29}$. Other authors comment on the fact that a diagnosis of cancer brings many doubts and lack of security and could even lead to psychiatric disorders. These disorders are usually considered as belonging to one of two basic groups, namely anxiety, and depression. Depression is one of the psychiatric disorders that is hardest to diagnose in cancer patients, due to the similarity of symptoms between cancer and the adverse effects of their treatment, which often prevail over the symptoms of this disorder ${ }^{30}$.

Chronic inflammation is also shown as a pro-tumoral factor, leading to a tumor's aggressive growth and spread. Many inflammatory factors that trigger tumor growth are also responsible for syndromes such as anorexia and cachexia, pain, and shortened lifespan ${ }^{31}$.

Pedroso, Araújo and Stevanato ${ }^{28}$ said that this chronic inflammation is related to the increased mass of body fat, with the adipose tissue being an important source of circulatory pro-inflammatory cytokines. In this way, the loss of weight would reduce the production of pro-inflammatory cytokines (IL-6, TNF) and increase the production of anti-inflammatory agents (IL-10, IL-1ra). For this, the reduction in calorie intake and an increase in physical exercise would work as effective strategies for the general reduction of inflammation.

In the sample, we saw that a minority of people interviewed (13\%) were aware of the palliative diagnosis, while the majority of the subjects $(87 \%)$ we not aware of. When the issue turns to the primary diagnosis, we saw that over half the subjects were aware of the diagnosis of cancer, and 35\% did not know about it. Several factors could play a part in the non-encoding of the message on the doctor-patient axis $^{32,33}$. The doctor must pay attention throughout his or her discourse to behaviors such as the use of technical jargon and constant interruptions while the patient is speaking. Technical terms should only be used when absolutely necessary, together with a clarification as to why they are used. And interruptions should be discouraged, using another method, which is that of guiding the conversation to what is most relevant.

Simpson et al..$^{34}$, identified problems with the language used by medical professionals, generally related to lack of clarity, excessive use of jargon, and restricted sharing of meanings of expressions used, between the doctor and patient. In the opinion of Beckman and Frankel ${ }^{35}$, the continuous interruption of the patient's talk causes some inhibition and retraction when the patient has something else to say.

Communication between doctor and patient should offer conditions so that there may be the promotion of health, making the user/ caregiver autonomous to negotiate with regard to treatment and to conditions that favor self-care ${ }^{36}$. When caring for cancer patients, we often come across communication of bad news $(\mathrm{BN})$ which can involve not only the unveiling of the actual diagnosis but also the worsening of the disease and the need to be sent for PC and home care. Most doctors agree that the best way to give $\mathrm{BN}$ is through a patient-centered approach, in which the information is given gradually and steadily, while also, at the same time, encouraging them to talk about their feelings and concerns, both now and in the future. This kind of communication needs professional preparation and training ${ }^{37}$.

Another justification for the data found in this study is when patient and family have different ideas about the treatment to be given, or about life-end issues, making communication ineffective. The family meets challenges, and not only the requirements of the caring role but also the 
pain caused by the possibility of the death of the family member. As an important element in the last days of the patient's life, sometimes in a move to protect the patient from additional suffering, they ask the doctor not to give all the information about diagnosis and prognosis, thus establishing the "conspiracy of silence" or the "pact of silence."

The pact or conspiracy of silence is described ${ }^{38,39}$ as an implicit or explicit agreement between family members, friends, and professionals, to change the information that is passed on to the patient, to hide the diagnosis or the severity of the situation ${ }^{40}$.

On the other hand, in some countries, the reality of advance healthcare directives is already present and has been so for some time ${ }^{41}$. In Brazil, there is no specific legislation on this matter, but this is made known within the medical environment, through a Resolution passed by the Federal Medicine Council (CFM).

It was observed that the whole sample $(100 \%)$ is not aware of advance healthcare directives. To address this issue with the patient, it is necessary that the doctor should first address issues that are so often procrastinated, such as prognosis, death and PC, facing social issues such as low educational level, and cultural issues, which often help to make communication more difficult. However, these factors should not prevent communication and knowledge from the patients.

Another relevant item of data is the fact that over half the sample $(82 \%)$ does not use the Internet to find out more about their diagnosis. The Internet is a significant tool for information and communication and has become more and more readily available to the general population. Information about advance healthcare directives, diagnoses, and medical conduct can easily be found on the e-world.

\section{CONCLUSION}

The present study showed a significant lack of awareness that still affects patients in PC. Information such as diagnosis and treatment are not yet clear. Factors such as educational level, origin, improper use of drugs for pain relief: these are just some of the factors that have a direct influence on the implementation of PC. Habits such as lack of physical exercises could make the illness worse, or limit the prognosis of the client within his or her biological, psychological or social context.

\section{REFERENCES}

1. Carvalho RT, Parsons HA (org.). Manual de Cuidados Paliativos ANCP. $2^{\mathrm{a}}$ ed. Sấo Paulo: ANCP; 2012. 40-42p.

2. Magalhães JC. Cuidar em fim de vida: experiências durante a formação inicial de enfermagem. Lisboa: Coisas de Ler; 2009. 109p.

3. Davies E, Higginson IJ. Better palliative care for older people. Copenhagen: WHO; 2004.

4. Menezes RA, Ventura M. Ortotanásia, sofrimento e dignidade: entre valores morais, medicina e direito. Rev Bras Ciênc Soc. 2013;28(81):213-29

5. Conselho Federal de Medicina (Brasil). Resolução n ${ }^{\circ} 1.931$, de 17 de setembro de 2009. Código de Ética Médica. Diário Oficial da Uniẫo 24 set 200; Seçâo I.

6. Smith R. A good death. BMJ. 2000;320:129-30.

7. Conselho Federal de Medicina (Brasil). Resoluçăo no 1.995 , de 09 de agosto de 2012. Dispóe sobre as diretivas antecipadas de vontade dos pacientes. Diário Oficial da Uniāo 31 ago 2012; Seção I.

8. Rustøen T, Cooper BA, Miaskowski C. The importance of hope as a mediator of psychological distress and life satisfaction in a community sample of cancer patients. Cancer Nurs. 2010;33(4):258-67.

9. Chan EY, Wu HY, Chan YH. Revisiting the palliative performance scale: change in scores during disease trajectory predicts survival. Palliat Med. 2012;27(4):367-74.

10. Bruera E, Kuehn N, Miller MJ, Selmser P, Macmillan K. The Edmonton Symptom Assessment System (ESAS): a simple method for the assessment of palliative care patients. J Palliat Care. 1991:7(2):6-9.

11. Monteiro DR, Kruse MH, Almeida MA. Avaliaçấo do instrumento Edmonton Symptom Assessment System em cuidados paliativos: revisăo integrativa. Rev Gaúcha Enferm. 2010;31(4):785-93.

12. Alves JED. A transição demográfica e a janela de oportunidade. Săo Paulo: Instituto Fernand Braudel de Economia Mundial; 2008.

13. Carneiro LAF, Campino ACC, Leite F, Rodrigues CG, Santos GMM, Silva ARA. Envelhecimento populacional e os desafios para o sistema de saúde brasileiro. São Paulo: Instituto de Estudos de Saúde Suplementar; 2013.

14. Ministério do Planejamento Orçamento e Gestấo. Sinopse do censo demográfico 2010. Brasília: Instituto Brasileiro de Geografia e Estatística. [acesso em 10 out 2016]. Disponível em: http://www.censo2010.ibge.gov.br/

15. Carvalho FP, Silva SK, Oliveira LC, Fernandes AC, Solano LC, Barreto EL. Conhecimento acerca da política nacional de atençấo integral à saúde do homem na estratégia de saúde da família. Rev APS. 2016;16(4):386-92.

16. Yildirim Y, Kocabiyik $S$. The relationship between social support and loneliness in Turkish patients with cancer. J Clin Nurs. 2010;19(5-6):832-9.

17. Prade CF, Casellato G, Silva AL. Cuidados Paliativos e comportamento perante a morte. In: Knobel E (ed.). Psicologia e humanização: assistência aos pacientes grave. São Paulo: Atheneu; 2008. 149-158p.

18. Paiva EP, Motta MC, Griep RH. Conhecimentos, atitudes e práticas acerca da detecção do câncer de próstata. Acta Paul. Enferm. 2010;23(1):88-93.

19. Höfelmann DA, Anjos JC, Ayala AR. Sobrevida em dez anos e fatores prognósticos em mulheres com câncer de mama em Joinville, Santa Catarina, Brasil. Ciênc Saúde Coletiva. 2014:19(6);1813-24.

20. Thuler LCS, Bergmann A, Casado L. Perfil das pacientes com câncer do colo do útero no Brasil, 2000-2009: estudo de base secundária. Rev Bras Cancerol. 2012;58(3):351-7.

21. Albano JD, Ward E, Jemal A, Anderson R, Cokkinides VE, Murray T, et al. Cancer mortality in the United States by education level and race. Natl Cancer Inst. 2007;99(18):1384-94.

22. Hossne WS. Relação médico-paciente: competência do médico. In: Segre M, Cohen C (org.). Bioética. $3^{a}$ ed. São Paulo: Edusp; 2002. 106-18p.

23. Mourão CM, Albuquerque MA, Silva AP, Oliveira MS, Fernandes AF. Comunicação em enfermagem: uma revisăo bibliográfica. Rev Rene. 2009;10(3):139-45.

24. Brasil, Ministério da Saúde. Instituto Nacional de Câncer. Cuidados Paliativos Oncológicos: controle da dor. Rio de Janeiro: INCA; 2001.

25. Costa AI, Chaves MD. Dor em paciente oncológico sob tratamento quimioterápico. Rev Dor. 2012;13(1):45-9.

26. Miceli AV. Dor crônica e subjetividade em oncologia. Rev Bras Cancerol. 2002;48(3):363-73.

27. Courneya KS, Friedenreich CM, Sela RA, Quinney HA, Rhodes RE. Correlates of adherence and contamination in a randomized controlled trial of exercise in cancer survivors: an application of the theory of planned behavior and the five factor model of personality. Ann Behav Med. 2002;24(4):257-68

28. Pedroso W, Araújo MB, Stevanato E. Atividade física na prevenção e na reabilitação do câncer. Motriz. 2005;11(3):155-60.

29. Lucchese R, Sousa K, Bonfin SP, Vera I, Santana FR. Prevalência de transtorno mental comum na atenção primária. Acta Paul Enferm. 2014;27(3):200-7.

30. Stark DP, House A. Anxiety in cancer patients. Br J Cancer. 2000;83(10):1261-7.

31. Caperuto E, Navarro F. Lipídios, patologias associadas e exercício: câncer/caquexia. In: Lima WP. (org.). Lipídios e exercício: aspectos fisiológicos e do treinamento. São Paulo: Phorte; 2009. 119-30p.

32. Nassar P. Tudo é comunicaçẫo. São Paulo: Lazuli; 2003. 118-120p.

33. Lévy P. Árvores de Saúde. Interface. 1999;3(4):143-56.

34. Simpson M, Buckman R, Stewart M, Maguire P, Lipkin M, Novack D, et al. Doctor-patient communication: the Toronto consensus statement. BMJ. 1991;303(6814):1385-7.

35. Beckman HB, Frankel RM. The effect of physician behavior on the collection of data. Ann Intern Med. 1984;101(5):692-6.

36. Fiedler RC. A teoria da açáo comunicativa de Habermas e uma nova proposta de desenvolvimento e emancipaçáo do humano. Rev Educ. 2006;I(1):93-100.

37. Hancock K, Clayton JM, Parker SM, Walder S, Butow PN, Carrick S, et al. Discrepant perceptions about endof-life communication: a systematic review. J Pain Symptom Manage. 2007;34(2):190-200.

38. Chaturvedi SK, Loiselle CG, Chandra PS. Communication with relatives and collusion in palliative care: A cross-cultural perspective. Indian J Palliat Care. 2009;15(1):2-9.

39. Bermejo J, Villacieros M, Carabias R, Sánchez E, Díaz-Albo B. Conspiración del silencio en familiares y pacientes al final de la vida ingresados en una unidad de cuidados paliativos: nivel de información y actitudes observadas. MEDIPAL. 2013;20(2):49-59.

40. Takieldin MA. Impacto social y familiar ante la enfermedad incurable. MEDPAL, Interdisciplina y Domicilio. 2010;2(3):13-15.

41. Dadalto L. Testamento Vital. 2a ed. Rio de Janeiro: Lumen Juris; 2013. 95-156p. 